\title{
Communication \\ Chemical Constituents and Antifungal Activity of Ficus hirta Vahl. Fruits
}

\author{
Chunpeng Wan ${ }^{1}$, Chuying Chen ${ }^{1}$, Mingxi Li ${ }^{1}$, Youxin Yang ${ }^{1}$, Ming Chen ${ }^{1}$ and Jinyin Chen ${ }^{1,2, *}$ \\ 1 Jiangxi Key Laboratory for Postharvest Technology and Nondestructive Testing of Fruits \& Vegetables; \\ Collaborative Innovation Center of Post-Harvest Key Technology and Quality Safety of Fruits and \\ Vegetables; College of Agronomy, Jiangxi Agricultural University, Nanchang 330045, China; \\ chunpengwan@jxau.edu.cn (C.W.); ccy0728@126.com (C.C.); liming.xi@hotmail.com (M.L.); \\ yangyouxin@jxau.edu.cn (Y.Y.); chenming@jxau.edu.cn (M.C.) \\ 2 Pingxiang University, Pingxiang 337055, China \\ * Correspondence: jinyinchen@126.com; Tel.: +86-791-8381-3058
}

Received: 1 September 2017; Accepted: 25 September 2017; Published: 27 September 2017

\begin{abstract}
Phytochemical investigation of Ficus hirta Vahl. (Moraceae) fruits led to isolate two carboline alkaloids (1 and 2), five sesquiterpenoids/norsesquiterpenoids (3-7), three flavonoids (8-10), and one phenylpropane-1,2-diol (11). Their structures were elucidated by the analysis of their 1D and 2D NMR, and HR-ESI-MS data. All of the isolates were isolated from this species for the first time, while compounds 2, 4-6, and 8-11 were firstly reported from the genus Ficus. Antifungal assay revealed that compound 8 (namely pinocembrin-7-O- $\beta$-D-glucoside), a major flavonoid compound present in the ethanol extract of $F$. hirta fruits, showed good antifungal activity against Penicillium italicum, the phytopathogen of citrus blue mold caused the majority rotten of citrus fruits.
\end{abstract}

Keywords: Ficus hirta; Moraceae; carboline alkaloids; sesquiterpenoids; flavonoids; antifungal

\section{Introduction}

The genus Ficus (Moraceae) contains more than 1000 species, most of them are distributed in tropical, sub-tropical, and Mediterranean regions [1]. There are around 98 species distributed in the South of China. Ficus hirta Vahl. is mainly distributed in Yunnan, Guizhou, Guangxi, Guangdong and Hainan province, China [1]. The fruits of F. hirta were used as medicine and food resource by the local people of Guangdong province, China. Previous chemical investigations on the F. hirta focused on its roots, which led to isolate and identify the predominant chemical constituents, flavonoids, and coumarins. To date, the total of 31 flavonoids [2-7] and 7 coumarins $[2,3,5,8]$ have been reported from this species. Except the flavonoids and coumarins, there are some other compounds reported from this species, such as steroids [2,7] and benzoic acid derivatives [7].

Several studies on the pharmacological activities of $F$. hirta showed its antioxidation [9], cytotoxicity, and apoptosis of HeLa cells [10]; anti-inflammation and analgesia [11], antitussive and antiasthmatic [12], hepatoprotective [13], and radioresistance effects [14]. The fruits of $F$. hirta consumed as a plant-derived food that showed potential tonic effects [15]. Besides mentioned above, F. hirta also showed antibacterial activity against Escherichia coli, Staphylococcus aureus [16], and Penicillium italicum, a phytopathogenic cause of citrus blue mold resulted in the destructive fruit rotten of citrus. The fruits of $F$. hirta and several other medicinal plants were also used to control the phytopathogen in order to decrease the loss of citrus rotten $[17,18]$. The fruits of $F$. hirta showed promising antifungal activity against $P$. italicum and prolonged the Nanfeng mandarin preservation period [19], while the major antifungal constituents were not clear until now. 
In order to continue our studies on isolation and identification of the antifungal compounds from plants. We have elucidated the antifungal constituents of $F$. hirta fruits. Fortunately, our previous studies have identified nine monosubstituted benzene derivatives from the extracts of $F$. hirta fruits and some of them showed good antifungal activities $[17,18]$, while they were not the major antifungal constituents for their low content in the plant. In continuation, the current study was aimed to discover the major antifungal compounds with diverse structures from this species.

\section{Results}

As described previously, the ethanol extracts (FH) of the fruits of F. hirta and the fractions (FH1-FH4) fractionated by D101 macro resin column were evaluated for their antifungal activities against $P$. italicum. Fractions $\mathrm{FH} 2-\mathrm{FH} 4$ showed stronger antifungal activities in a concentration-dependent manner than that of FH crude extract [18]. The further isolation was focused on the fractions with potent antifungal activities to find more active compounds present in the fruits of F. hirta.

As a result, 11 compounds (1-11) (Figure 1) were isolated from those fractions, and their structures were elucidated based on the analysis of spectroscopic data (including HR-ESI-MS, ${ }^{1} \mathrm{H}-\mathrm{NMR},{ }^{13} \mathrm{C}-\mathrm{NMR}$, and 2D NMR) and comparison of these data to previous published paper. The 11 compounds were determined as 1 -methyl-1,2,3,4-tetrahydro- $\beta$-carboline-3-carboxylic acid (1) [20], methyl 1-methyl-1,2,3,4-tetrahydro- $\beta$-carboline-3-carboxylate (2) [21], vomifoliol (3) [22], dehydrovomifoliol (4) [22], icariside $B_{2}$ (5) [23], dihydrophaseic acid (6) [24], pubinernoid A (7) [25], pinocembrin-7-O- $\beta$-D-glucoside (8) [26], naringenin-7-O- $\beta$-D-glucoside (9) [27], eriodictyol-7-O- $\beta$-D-glucoside (10) [28], and 1-phenylpropane-1,2-diol (11) [29]. All of the isolates were isolated from this species for the first time, while compounds 2, 4-6, and 8-11 were first reported from the genus Ficus.

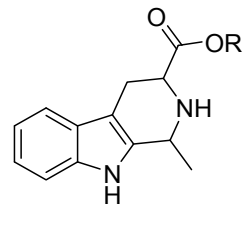

$1 \mathrm{R}=\mathrm{H}$

$2 \mathrm{R}=\mathrm{CH}_{3}$

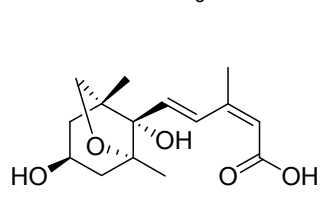

6<smiles>CC1=CC(=O)CC(C)(C)C1/C=C/C(C)O</smiles>

3

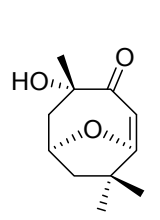

7

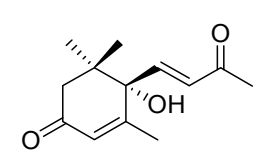

4

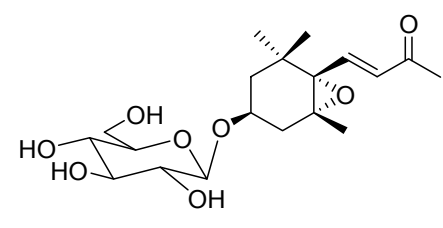

5

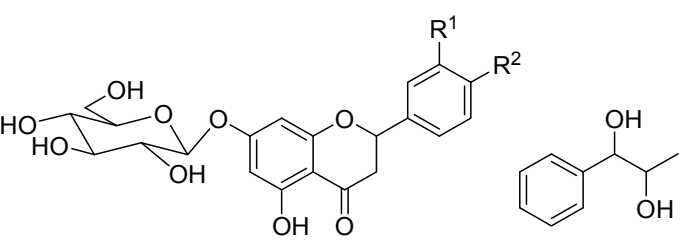

$8 \mathrm{R}^{1}=\mathrm{R}^{2}=\mathrm{H}$ $9 \mathrm{R}^{1}=\mathrm{H}, \mathrm{R}^{2}=\mathrm{OH}$ $10 \mathrm{R}^{1}=\mathrm{R}^{2}=\mathrm{OH}$

Figure 1. Structures of the compounds isolated from the fruits of Ficus hirta.

Compound 5, was obtained as colorless amorphous solid, displayed a molecular formula of $\mathrm{C}_{19} \mathrm{H}_{30} \mathrm{O}_{8}$ as determined by HRESIMS at $m / z 409.1822[\mathrm{M}+\mathrm{Na}]^{+}$(calcd. for $\mathrm{C}_{19} \mathrm{H}_{30} \mathrm{O}_{8} \mathrm{Na}, 409.1838$ ). In the ${ }^{1} \mathrm{H}-\mathrm{NMR}$ spectrum, four tertiary methyls signals $\left(\delta_{\mathrm{H}} 2.29,1.21,1.19,0.96\right.$, each $\left.3 \mathrm{H}, \mathrm{s}\right)$, a trans double bond protons signal at $\delta_{\mathrm{H}} 7.17(1 \mathrm{H}, \mathrm{d}, J=15.8 \mathrm{~Hz})$ and $6.18(1 \mathrm{H}, \mathrm{d}, J=15.8 \mathrm{~Hz})$, and an anomeric proton at $\delta_{\mathrm{H}} 4.34(1 \mathrm{H}, \mathrm{d}, J=7.0 \mathrm{~Hz})$, as well as oxygen-bearing methine protons at $\delta_{\mathrm{H}} 3.86(1 \mathrm{H}, \mathrm{m})$ were observed. The ${ }^{13} \mathrm{C}-\mathrm{NMR}$ and HSQC spectra revealed the presence of 19 carbon resonances, 6 of them were contributed to glucose. Analysis of the 1D and 2D NMR spectra data (including ${ }^{1} \mathrm{H}-{ }^{1} \mathrm{H}$ COSY, HSQC, HMBC) allowed for the establishment of the structure of 5 . The HSQC spectrum permitted the assignment of all of the protons to their bonding carbons. The ${ }^{1} \mathrm{H}-{ }^{1} \mathrm{H}$ COSY spectra (drawn with 
bold bonds in Figure 2) disclosed that compound 5 had three partial structure units (including a sugar moiety). Analysis of the HMBC spectrum then enabled the connectivity of these spin coupling fragments and the other functional groups. The HMBC correlations (Figure 2) from $\mathrm{H}_{3}-12\left(\mathrm{H}_{3}-13\right)$ to C-1, C-2, C-6, and C-13 (C-12); from H-11 to C-4, C-5, and C-6; from H-7 and H-8 to C-6; and from $\mathrm{H}_{3}-10$ to $\mathrm{C}-8$ and $\mathrm{C}-9$, allowed the construction of the planar structure of aglycone. The glucopyranose was linked to $\mathrm{C}-3$ by the HMBC correlation from $\mathrm{H}-1^{\prime}$ to $\mathrm{C}-3$. Searching the structure with SCIFINDER revealed it has the same planar structure as the NMR data of 5 with those of icariside $B_{2}$ indicated they had the same stereochemistry. Therefore, compound $\mathbf{5}$ was determined as icariside $B_{2}$.

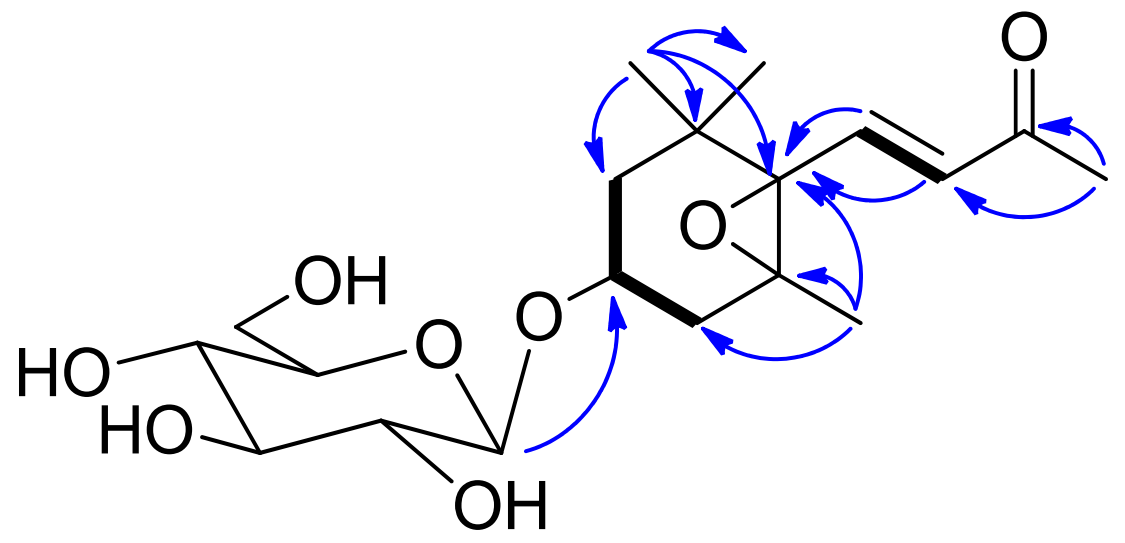

Figure 2. ${ }^{1} \mathrm{H}-{ }^{1} \mathrm{H}$ COSY (bold bonds) and HMBC (arrows) correlations of Compound 5.

Compound 6, had a molecular formula of $\mathrm{C}_{15} \mathrm{H}_{22} \mathrm{O}_{5}$ as determined by HRESIMS at $\mathrm{m} / \mathrm{z}$ $305.1349[\mathrm{M}+\mathrm{Na}]^{+}$(calcd. for $\mathrm{C}_{15} \mathrm{H}_{22} \mathrm{O}_{5} \mathrm{Na}, 305.1365$ ). The ${ }^{1} \mathrm{H}-\mathrm{NMR}$ spectrum showed a trans double bond signals at $\delta_{\mathrm{H}} 7.98(1 \mathrm{H}, \mathrm{d}, J=15.8 \mathrm{~Hz})$ and $6.52(1 \mathrm{H}, \mathrm{d}, J=15.8 \mathrm{~Hz})$, an olefinic proton signal at $\delta_{\mathrm{H}} 5.76(1 \mathrm{H}, \mathrm{s})$, an oxygenated methylene signal at $\delta_{\mathrm{H}} 3.80(1 \mathrm{H}, \mathrm{d}, J=7.4 \mathrm{~Hz})$ and $3.70(1 \mathrm{H}, \mathrm{d}, J=7.4 \mathrm{~Hz})$, and three tertiary methyls signals $\left(\delta_{\mathrm{H}} 2.08,1.15,0.93\right.$, each $\left.3 \mathrm{H}, \mathrm{s}\right)$. The ${ }^{13} \mathrm{C}-\mathrm{NMR}$ and HSQC spectra revealed the presence of 15 carbon signals, attributing to 3 methyls, 3 methylenes, 4 methines, and 5 quaternary carbons. Aforementioned data suggested that compound 6 was likely a sesquiterpenoid. Further analysis of 2D NMR $\left({ }^{1} \mathrm{H}-{ }^{1} \mathrm{H}\right.$ COSY, HSQC, and HMBC) data allowed us to determine the structure of 6 . The ${ }^{1} \mathrm{H}-{ }^{1} \mathrm{H}$ COSY correlations of $\mathrm{H}-2 / \mathrm{H}-3, \mathrm{H}-3 / \mathrm{H}-4$, and $\mathrm{H}-7 / \mathrm{H}-8$ indicated the presence of two structure units (drawn with bold bonds in Figure 3). The HMBC correlations (Figure 3) from $\mathrm{H}_{2}-12$ to $\mathrm{C}-1, \mathrm{C}-2, \mathrm{C}-5, \mathrm{C}-6$, and $\mathrm{C}-13$; from $\mathrm{H}_{3}-14$ to $\mathrm{C}-4, \mathrm{C}-5$, and C-6; from $\mathrm{H}-7$ and $\mathrm{H}-8$ to $\mathrm{C}-6$; from $\mathrm{H}_{3}-15$ to $\mathrm{C}-8, \mathrm{C}-9$ and $\mathrm{C}-10$; and from $\mathrm{H}-10$ to $\mathrm{C}-11$, constructed the planar structure of $\mathbf{6}$. Compared the NMR data of $\mathbf{6}$ with those of dihydrophaseic acid revealed they had the same structure. Therefore, compound 6 was elucidated as dihydrophaseic acid.

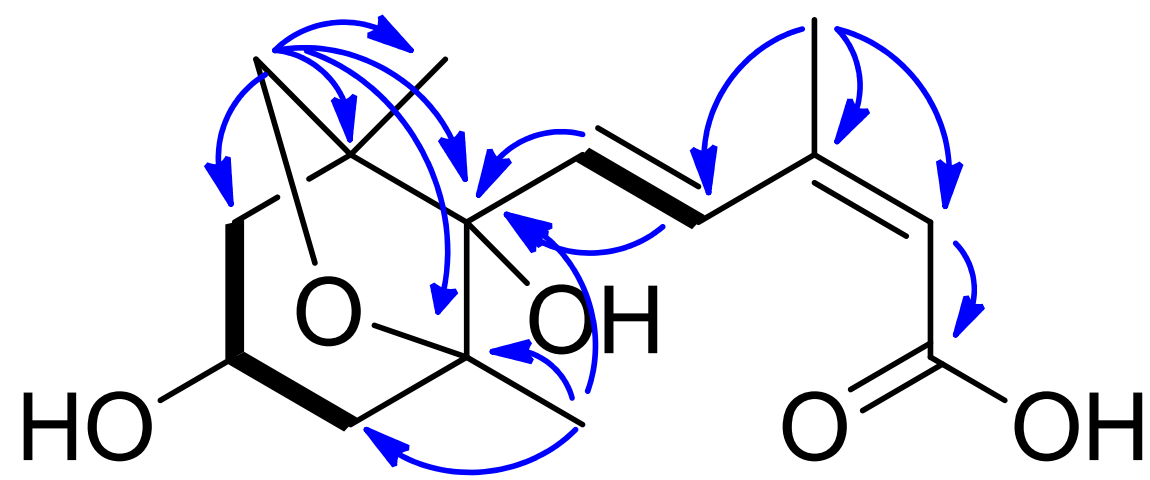

Figure 3. ${ }^{1} \mathrm{H}-{ }^{1} \mathrm{H}$ COSY (bold bonds) and HMBC (arrows) correlations of Compound 6. 
The antifungal activities of all of the isolates were tested at two concentrations ( 2.0 and $4.0 \mathrm{mg} / \mathrm{mL}$ ). The results showed that none of them except compound 8 showed antifungal activity with the DIZs of $19.0 \pm 0.5 \mathrm{~mm}$ and $24.0 \pm 0.5 \mathrm{~mm}$ at 2.0 and $4.0 \mathrm{mg} / \mathrm{mL}$, respectively, which are more powerful than that of $\mathrm{FH}(11.0 \pm 0.6 \mathrm{~mm}$ at $2.0 \mathrm{mg} / \mathrm{mL})$.

Moreover, compound $\mathbf{8}$ was also evaluated, its antifungal activity using mycelia growth method, the results are shown in Table 1. The inhibition rate was shown as concentration-dependent. Compound 8 exhibited more than $90 \%$ inhibitory effect against $P$. italicum at $400 \mu \mathrm{g} / \mathrm{mL}$, while $100 \%$ inhibition rate was achieved at $800 \mu \mathrm{g} / \mathrm{mL}$.

Table 1. Antifungal activity of Compound 8 tested by mycelia growth method

\begin{tabular}{cc}
\hline Concentration $(\mu \mathrm{g} / \mathrm{mL})$ & Inhibition Rate \\
\hline 25 & $13.70 \pm 1.81$ \\
50 & $36.88 \pm 1.08$ \\
100 & $56.10 \pm 2.55$ \\
200 & $74.65 \pm 1.61$ \\
400 & $92.05 \pm 1.55$ \\
800 & 100 \\
\hline
\end{tabular}

\section{Discussion}

The genus Ficus is characterized by flavonoids, coumarins, terpenoids (triterpenoids and sesquiterpenoids), and alkaloids [30]. In the current study, 11 compounds (1-11) were isolated and identified from the fruits of $F$. hirta, which were classified as carboline alkaloids (1 and 2), sesquiterpenoids/norsesquiterpenoids (3-7) and flavonoid glucosides (8-10). The structural classes of these isolates support the taxonomic placement of F. hirta in the genus Ficus. All of the chemical constituents are isolated from this species for the first time. Moreover, compounds 2, 4-6, and 8-11 are firstly reported from the genus Ficus. Compound $\mathbf{1}$ has been isolated from Ficus pumila [17], which is the only carboline alkaloid reported from the genus Ficus before the current study. Five sesquiterpenoids/norsesquiterpenoids (3-7) could be further classified as megastigmanes (3 and 5), carotenoid sesquiterpenoid (6), and norsesquiterpenoid with 11C skeleton (7). Vomifoliol (3) has been exclusively obtained from the species of Ficus platypoda and Ficus pumila before our study [17,31].

The discovery of compounds $\mathbf{1}$ and $\mathbf{3}$ showed the relevance between this species and other Ficus species such as F. platypoda and F. pumila. Compound $\mathbf{6}$ is a derivative of plant hormone abscisic acid that can be classified as carotenoid sesquiterpenoid, which is different from other sesquiterpenoids isolated from the genus Ficus $[32,33]$. Compound 7 is a norsesquiterpenoids with $11 \mathrm{C}$ skeleton with different linkage with other 11C skeleton norsesquiterpenoids previously isolated from Ficus microcarpa [34,35]. Previously, two isomers of "Eriodictyol hexoside" and other flavonoids were tentative identified in the fruits of F. carica using HPLC-MS approaches [36]. The identification of eriodictyol-7-O- $\beta$-D-glucoside (10) in F. hirta confirmed these results and showed the relevance between this species and F. carica.

Pinocembrin-7-O- $\beta$-D-glucoside (8) showed good antifungal activity while the compounds 9 and 10 showed none activity, which indicated the antifungal activity of flavonoids maybe effected by the number of hydroxyl in the $\mathrm{C}$ loop. This is the first time the antifungal activity of compound $\mathbf{8}$ against P. italicum has been reported. However, some references have already revealed the antifungal activity of its aglycone, namely pinocembrin $[37,38]$.

Overall, these results indicated that carboline alkaloid, megastigmanes, and flavonoids could be regarded as a chemotaxonomic marker of $F$. hirta. Also, while only one carotenoid sesquiterpenoid and a norsesquiterpenoid with $11 \mathrm{C}$ skeleton were identified herein, whether they may be regarded as a chemotaxonomic marker of $F$. hirta species remains to be established. Pinocembrin-7-O- $\beta$-D-glucoside (8) was the major antifungal constituent against $P$. italicum existed in the fruits of Ficus hirta. 


\section{Materials and Methods}

\subsection{Plant Material}

The fruits of F. hirta were bought from Zhangshu medicinal market, Jiangxi Province, China, and authenticated by Prof. Shouran Zhou (College of Basic Medicine, Jiangxi University of Traditional Chinese Medicine). A voucher specimen (no. FH-201406) was deposited in the herbarium of Jiangxi Key Laboratory for Postharvest Technology and Nondestructive Testing of Fruits \& Vegetables, Jiangxi Agricultural University (Nanchang, Jiangxi, China).

\subsection{Equipment and Reagents}

${ }^{1} \mathrm{H}$ - and ${ }^{13} \mathrm{C}-\mathrm{NMR}$ spectral data were tested on a Varian $400 \mathrm{MHz}$ Nuclear magnetic resonance spectrometer with Tetramethylsilane (TMS) as internal standard. HR-ESI-MS were detected on a TripleTOFT 5600 LC/MS/MS (Applied Biosystems MDS, Foster City, CA, USA) mass spectrometer. Medium pressure liquid chromatography (MPLC) was carried out on a C-605 pump (BUCHI, Flawil, Switzerland) coupled with a reverse phase C18 column $(3.6 \times 46 \mathrm{~cm})$. HPLC was conducted on a Hitachi Elite Chromaster system-consisting of a 5210 autosampler, 5110 pump, 5430 diode array detector, and 5310 column oven-which were operated by EZChrom Elite software. Luna C18 column $(5 \mu \mathrm{m}, 4.6 \times 250 \mathrm{~mm})$ for analysis and Luna C18 column $(5 \mu \mathrm{m}, 10 \times 250 \mathrm{~mm})$ for semi-preparative HPLC were purchased from Phenomenex Inc. (Torrance, CA, USA). The HPLC grade solvents were purchased from Sigma (Sigma, St. Louis, MO, USA). All analytical solvents were bought from Tansoole (Shanghai, China).

\subsection{Extraction and Chromatography}

The air dried fruits of F. hirta $(4.9 \mathrm{~kg})$ were ground and extracted using ultrasonic-assisted method with $95 \%$ ethanol $(3 \times 25 \mathrm{~L})$ at $25{ }^{\circ} \mathrm{C}$ for $90 \mathrm{~min}$. The extract were evaporated to remove ethanol solvent and yielded the dried ethanol extract (345.1 g), which was subjected to D101 macro rein column chromatography eluted with water, 30\% ethanol $(v / v), 50 \%$ ethanol, and 95\% ethanol, respectively, to yield four fractions (FH1-FH4). Antifungal activity test indicated that three fractions (FH2-FH4) were the active fractions. Activity-guided isolation were performed accordingly, as follows.

The $30 \%$ ethanol fraction $\mathrm{FH} 2(113.6 \mathrm{~g})$ was subjected to $\mathrm{C}_{18}$ silica gel column $(3.6 \times 46 \mathrm{~cm})$ chromatography elution with $\mathrm{MeOH} / \mathrm{H}_{2} \mathrm{O}\left(\mathrm{MeOH} / \mathrm{H}_{2} \mathrm{O}, 15 / 85\right.$ to $\left.25 / 75, v / v\right)$ to yield five fractions (FH2a-FH2e). Fraction FH2c was separated on Sephadex LH-20 and eluted with MeOH to give six combined sub-fractions (FH2c1-FH2c6). Fraction FH2c2 was subjected to Sephadex LH-20 elution with $\mathrm{MeOH}$ to give five sub-fractions (FH2c2a-FH2c2e). Sub-fraction $\mathrm{FH} 2 \mathrm{c} 2 \mathrm{c}$ was purified using silica gel column chromatography using $\mathrm{CH}_{3} \mathrm{Cl}-\mathrm{MeOH}(10: 1$ to $1: 1, v / v)$ for elution to give compound 1 $(12.0 \mathrm{mg})$ and two sub-fractions (FH2c2c1 and $\mathrm{FH} 2 \mathrm{c} 2 \mathrm{c} 2)$. Purification of FH2c2c1 with semi-preparative HPLC, eluting with MeOH-H ${ }_{2} \mathrm{O}$ (0-25 min: 20:80 to 55:45; 25-26 min: 55:45 to 100:0; 26-27 min: 100:0; 27-28 min: $100: 0$ to 20:80; 28-35 $\mathrm{min}: 20: 80 ; v / v, 3 \mathrm{~mL} / \mathrm{min})$, yielded compound 5 (2.4 mg). Fraction $\mathrm{FH} 2 \mathrm{c} 2 \mathrm{~d}$ was subjected to silica gel column chromatography eluted with $\mathrm{CH}_{3} \mathrm{Cl}-\mathrm{MeOH}(100: 1$ to $1: 1$, $v / v)$ to get seven fractions (FH2c2d1-FH2c2d7).

Purification of fraction FH-2C2d1 with semi-preparation HPLC, eluting with $\mathrm{MeOH}-\mathrm{H}_{2} \mathrm{O}$ (0-25 min: $20: 80$ to $68: 32 ; 25-26 \mathrm{~min}: 68: 32$ to 100:0; 26-27 $\mathrm{min}: 100: 0 ; 27-28 \mathrm{~min}: 100: 0$ to 30:70; 28-35 min: 30:70; $v / v, 3 \mathrm{~mL} / \mathrm{min})$, yielded compound 4 (3.6 mg).

Fraction $\mathrm{FH} 2 \mathrm{c} 2 \mathrm{~d} 2$ was purified by semi-preparative HPLC, eluting with $\mathrm{MeOH}-\mathrm{H}_{2} \mathrm{O}(0-20$ min: 20:80 to 51:49; 20-21 min: 51:49 to 100:0; 21-22 min: 100:0; 22-23 min: 100:0 to 20:80; 23-30 min: 20:80; $v / v, 3 \mathrm{~mL} / \mathrm{min})$, yielded compounds $7(4.0 \mathrm{mg})$ and $11(4.5 \mathrm{mg})$. Fraction FH2c2d5 was subjected on Sephadex LH-20 eluted with $\mathrm{MeOH}$ to give three sub-fractions (FH2c2d5a-FH2c2d5c). Purification of FH2c2d5b with semi-preparative HPLC, eluting with $\mathrm{MeOH}-\mathrm{H}_{2} \mathrm{O}(0-35 \mathrm{~min}$ : 30:70 to 34:66; 35-36 min: 34:66 to 100:0; 36-37 min: 100:0; 37-38 min: 100:0 to 30:70; 38-45 min: 30:70; v/v, $3 \mathrm{~mL} / \mathrm{min}$ ), yielded compounds $2(3.2 \mathrm{mg})$ and $6(8.2 \mathrm{mg})$. Fraction FH2c3 was purified by semi-preparative HPLC, 
eluting with $\mathrm{MeOH}-\mathrm{H}_{2} \mathrm{O}$ (0-21 min: $20: 80$ to 55:45; $21-22 \mathrm{~min}: 55: 45$ to 100:0; $22-23 \mathrm{~min}$ : 100:0; 23-24 min: 100:0 to 20:80; $24-31 \mathrm{~min}: 20: 80 ; v / v, 3 \mathrm{~mL} / \mathrm{min}$ ), yielded compound 3 (9.7 mg). Fraction FH2d was separated on Sephadex LH-20 eluted with $\mathrm{MeOH}$ to give eleven combined sub-fractions (FH2d1-FH2d11). Fraction FH2d6 was recrystallized with methanol to yield compound $\mathbf{1 0}$ (15.4 mg).

The $50 \%$ ethanol fraction FH3 (35.5 g) was subjected to $\mathrm{C}_{18}$ silica gel column chromatography eluted with $\mathrm{MeOH} / \mathrm{H}_{2} \mathrm{O}\left(\mathrm{MeOH} / \mathrm{H}_{2} \mathrm{O}, 40 / 60\right.$ to $70 / 30$, v/v) to yield six fractions FH3a-FH3f. Fraction FH3c was separated on Sephadex LH-20 eluted with $\mathrm{MeOH}$ to give eight combined sub-fractions (FH3c1-FH3c8). Fraction FH3c7 was recrystallized with methanol to yield compound 9 (13.2 mg).

The 95\% ethanol eluted fraction FH4 (7.2 g) was separated over a column of Sephadex LH-20 eluted with $\mathrm{MeOH}$ to give eight combined sub-fractions (FH4a-FH4h). Fraction FH4e was recrystallized with methanol to yield compound $8(21.5 \mathrm{mg})$.

\subsection{Antifungal Activity Test}

The antifungal activity of FH extracts and isolates against $P$. italicum was evaluated by the Oxford Cup method as described previously [17,18].

The antifungal activity of the pure compound 8 (pinocembrin-7-O- $\beta$-D-glucoside) against P. italicum were further examined by the mycelia growth method as described previously [17]. Briefly, the pure compound 8 were dissolved in 95\% ethanol, and then added to the sterile PDA (potato dextrose agar) culture medium at the specified concentrations. The mixed media were then poured into plastic Petri dishes $(90 \mathrm{~mm})$. The agar-mycelial plugs $(6 \mathrm{~mm})$ infected with pathogens were incubated at the center of the Petri dishes sealed with parafilm and incubated in the dark. Mycelium colony growth diameters were measured when the fungal mycelium of the control group had completely covered the Petri dishes. All treatments were tested in six replicates. The inhibition of mycelial growth (IMG, \%) was calculated as the following formula: IMG $(\%)=100 \times(\mathrm{dc}-\mathrm{dt}) /(\mathrm{dc}-6)$, where $\mathrm{dc}$ and $\mathrm{dt}$ were the mycelium diameters $(\mathrm{mm})$ of the control and the treatment, respectively.

\subsection{NMR and MS Data of Compounds 1-11}

The ${ }^{1} \mathrm{H}$ - and ${ }^{13} \mathrm{C}$-NMR data of these compounds (1-11) were listed as follows.

Compound 1 HR-ESI-MS $m / z 231.1130\left[\mathrm{M}+\mathrm{H}^{+},{ }^{1} \mathrm{H}-\mathrm{NMR}\right.$ (400 MHz, DMSO- $\left.d_{6}\right) \delta$ : $4.52(1, \mathrm{H} \mathrm{d}, J=6.0 \mathrm{~Hz}, \mathrm{H}-1), 3.64(1 \mathrm{H}, \mathrm{dd}, J=4.5,12.0 \mathrm{~Hz}, \mathrm{H}-3), 2.78(1 \mathrm{H}, \mathrm{m}, \mathrm{H}-4 \mathrm{~b})$, $7.45(1 \mathrm{H}, \mathrm{d}, J=7.8 \mathrm{~Hz}, \mathrm{H}-5), 7.01(1 \mathrm{H}, \mathrm{t}, J=7.2 \mathrm{~Hz}, \mathrm{H}-6), 7.10(1 \mathrm{H}, \mathrm{t}, J=7.2 \mathrm{~Hz}, \mathrm{H}-7)$, $7.34(1 \mathrm{H}, \mathrm{d}, J=7.8 \mathrm{~Hz}, \mathrm{H}-8), 3.18(1 \mathrm{H}, \mathrm{dd}, J=4.5,15.3 \mathrm{~Hz}, \mathrm{H}-4 \mathrm{a}), 1.63\left(3 \mathrm{H}, \mathrm{d}, J=6.2 \mathrm{~Hz}, \mathrm{CH}_{3}\right) .{ }^{13} \mathrm{C}-\mathrm{NMR}$ (100 MHz, DMSO- $d_{6}$ ) 8: 49.5 (C-1), 58.1 (C-3), 23.7 (C-4), 118.5 (C-5), 119.3 (C-6), 121.8 (C-7), 111.7 (C-8), 107.2 (C-4a), 126.6 (C-4b), 136.8 (C-8a), 132.7 (C-9), 17.4 (C-10), 170.0 (C-11).

Compound 2 HR-ESI-MS $m / z 245.1284[\mathrm{M}+\mathrm{H}]^{+},{ }^{1} \mathrm{H}-\mathrm{NMR}\left(400 \mathrm{MHz}, \mathrm{CD}_{3} \mathrm{OD}\right) \delta: 4.60(1 \mathrm{H}, \mathrm{dd}, J=5.3$, $12.0 \mathrm{~Hz}, \mathrm{H}-1), 3.95\left(3 \mathrm{H}, \mathrm{s}, \mathrm{OCH}_{3}\right), 3.59(1 \mathrm{H}, \mathrm{dd}, J=4.8,11.2 \mathrm{~Hz}, \mathrm{H}-3), 3.52(1 \mathrm{H}, \mathrm{t}, J=6.0 \mathrm{~Hz}$, $\mathrm{H}-4 \mathrm{~b}), 7.50(1 \mathrm{H}, \mathrm{d}, J=7.8 \mathrm{~Hz}, \mathrm{H}-5), 7.07(1 \mathrm{H}, \mathrm{t}, J=7.2 \mathrm{~Hz}, \mathrm{H}-6), 7.16(1 \mathrm{H}, \mathrm{t}, J=7.2 \mathrm{~Hz}, \mathrm{H}-7)$, $7.37(1 \mathrm{H}, \mathrm{d}, J=7.8 \mathrm{~Hz}, \mathrm{H}-8), 3.14(1 \mathrm{H}, \mathrm{m}, \mathrm{H}-4 \mathrm{~b}), 1.78\left(3 \mathrm{H}, \mathrm{d}, J=6.2 \mathrm{~Hz}, \mathrm{CH}_{3}\right) .{ }^{13} \mathrm{C}-\mathrm{NMR}(100 \mathrm{MHz}$, $\left.\mathrm{CD}_{3} \mathrm{OD}\right)$ 8: 50.2 (C-1), 55.6 (C-3), 22.3 (C-4), 117.7 (C-5), 119.4 (C-6), 122.3 (C-7), 110.0 (C-8), 104.6 (C-4a), 125.7 (C-4b), 137.2 (C-8a), 129.4 (C-9), 15.6 (C-10), $169.0(\mathrm{C}-11), 52.5\left(\mathrm{OCH}_{3}\right)$.

Compound 3 HR-ESI-MS $m / z 247.1291[\mathrm{M}+\mathrm{Na}]^{+},{ }^{1} \mathrm{H}-\mathrm{NMR}\left(400 \mathrm{MHz}, \mathrm{CD}_{3} \mathrm{OD}\right) \delta: 1.00\left(3 \mathrm{H}, \mathrm{s}, \mathrm{CH}_{3}-11\right)$, $1.03\left(3 \mathrm{H}, \mathrm{s}, \mathrm{CH}_{3}-12\right), 1.24\left(3 \mathrm{H}, \mathrm{d}, J=6.8 \mathrm{~Hz}, \mathrm{CH}_{3}-10\right), 1.91\left(3 \mathrm{H}, \mathrm{d}, J=1.2 \mathrm{~Hz}, \mathrm{CH}_{3}-13\right)$, $2.16(1 \mathrm{H}, \mathrm{d}, J=16.4 \mathrm{~Hz}, \mathrm{H}-2 \mathrm{a}), 2.48(1 \mathrm{H}, \mathrm{d}, J=16.4 \mathrm{~Hz}, \mathrm{H}-2 \mathrm{~b}), 4.32(1 \mathrm{H}, \mathrm{dq}, J=6.4,6.4 \mathrm{~Hz}, \mathrm{H}-9)$, $5.78(1 \mathrm{H}, \mathrm{d}, J=16.0 \mathrm{~Hz}, \mathrm{H}-7), 5.80(1 \mathrm{H}, \mathrm{dd}, J=16.0,6.4 \mathrm{~Hz}, \mathrm{H}-8), 5.87(1 \mathrm{H}, \mathrm{q}, J=1.4 \mathrm{~Hz}, \mathrm{H}-4) .{ }^{13} \mathrm{C}-\mathrm{NMR}$ (100 MHz, CD $\left.{ }_{3} \mathrm{OD}\right)$ 8: 41.0 (C-1), 49.3 (C-2), 199.8 (C-3), 125.7 (C-4), 166.0 (C-5), 79.1 (C-6), 128.5 (C-7), 135.5 (C-8), 67.2 (C-9), 18.1 (C-10), 23.1 (C-11), 22.4 (C-12), 22.0 (C-13).

Compound 4 HR-ESI-MS m/z $221.1164[\mathrm{M}-\mathrm{H}]^{-},{ }^{1} \mathrm{H}-\mathrm{NMR}\left(400 \mathrm{MHz}, \mathrm{CD}_{3} \mathrm{OD}\right) \delta: 1.01\left(3 \mathrm{H}, \mathrm{s}, \mathrm{CH}_{3}-11\right)$, $1.06\left(3 \mathrm{H}, \mathrm{s}, \mathrm{CH}_{3}-12\right), 2.31\left(3 \mathrm{H}, \mathrm{s}, \mathrm{CH}_{3}-10\right), 1.90\left(3 \mathrm{H}, \mathrm{d}, J=1.2 \mathrm{~Hz}, \mathrm{CH}_{3}-13\right), 2.31(1 \mathrm{H}, \mathrm{d}, J=16.4 \mathrm{~Hz}$, 
H-2a), $2.62(1 \mathrm{H}, \mathrm{d}, J=16.4 \mathrm{~Hz}, \mathrm{H}-2 \mathrm{~b}), 6.98(1 \mathrm{H}, \mathrm{d}, J=16.0 \mathrm{~Hz}, \mathrm{H}-7), 6.43(1 \mathrm{H}, \mathrm{dd}, J=16.0,6.4 \mathrm{~Hz}$, $\mathrm{H}-8), 5.93$ (1H, s, H-4). ${ }^{13} \mathrm{C}-\mathrm{NMR}\left(100 \mathrm{MHz}, \mathrm{CD}_{3} \mathrm{OD}\right) \delta: 40.6$ (C-1), 49.1 (C-2), 189.9 (C-3), 126.6 (C-4), 163.2 (C-5), 78.6 (C-6), 146.9 (C-7), 130.3 (C-8), 199.2 (C-9), 26.2 (C-10), 22.1 (C-11), 23.3 (C-12), 17.7 (C-13).

Compound 5 HR-ESI-MS $m / z \quad 409.1822\left[\mathrm{M}+\mathrm{Na}^{+},{ }^{1} \mathrm{H}-\mathrm{NMR}\left(\mathrm{CD}_{3} \mathrm{OD}, 400 \mathrm{MHz}\right) \delta\right.$ : $7.17(1 \mathrm{H}, \mathrm{d}, J=15.8 \mathrm{~Hz}, \mathrm{H}-7), 6.18(1 \mathrm{H}, \mathrm{d}, J=15.8 \mathrm{~Hz}, \mathrm{H}-8), 4.34\left(1 \mathrm{H}, \mathrm{d}, J=7.0 \mathrm{~Hz}, \mathrm{H}-1^{\prime}\right)$, $3.86(1 \mathrm{H}, \mathrm{m}, \mathrm{H}-3), 3.12-3.83\left(6 \mathrm{H}\right.$, Sugar H-2' $\left., 3^{\prime}, 4^{\prime}, 5^{\prime}, 6^{\prime}\right), 2.42(1 \mathrm{H}, \mathrm{m}, \mathrm{H}-4), 2.29(3 \mathrm{H}, \mathrm{s}, \mathrm{H}-10)$, $1.81(1 \mathrm{H}, \mathrm{dd}, J=8.2,14.6 \mathrm{~Hz}, \mathrm{H}-4), 1.73(1 \mathrm{H}, \mathrm{m}, \mathrm{H}-2), 1.40(1 \mathrm{H}, \mathrm{m}, \mathrm{H}-2), 1.21(3 \mathrm{H}, \mathrm{s}, \mathrm{H}-13)$, 1.19 (3H, s, H-12), 0.96 (3H, s, H-11). ${ }^{13} \mathrm{C}-\mathrm{NMR}\left(\mathrm{CD}_{3} \mathrm{OD}, 100 \mathrm{MHz}\right)$ 8: 34.5 (C-1), 43.8 (C-2), 71.3 (C-3), 36.7 (C-4), 66.9 (C-5), 69.7 (C-6), 143.8 (C-7), 132.4 (C-8), 198.8 (C-9), 24.0 (C-10), 26.0 (C-11), 28.0 (C-12), 18.8 (C-13), $101.5\left(\mathrm{C}-1^{\prime}\right), 73.7\left(\mathrm{C}-2^{\prime}\right), 76.7\left(\mathrm{C}-3^{\prime}\right), 70.2\left(\mathrm{C}-4^{\prime}\right), 76.4\left(\mathrm{C}-5^{\prime}\right), 61.3\left(\mathrm{C}-6^{\prime}\right)$.

Compound 6 HR-ESI-MS $m / z 305.1349\left[\mathrm{M}+\mathrm{Na}^{+},{ }^{1} \mathrm{H}-\mathrm{NMR}\left(\mathrm{CD}_{3} \mathrm{OD}, 400 \mathrm{MHz}\right) \quad \delta\right.$ : $7.98(1 \mathrm{H}, \mathrm{d}, J=15.8 \mathrm{~Hz}, \mathrm{H}-4), 6.52(1 \mathrm{H}, \mathrm{d}, J=15.8 \mathrm{~Hz}, \mathrm{H}-5), 5.76(1 \mathrm{H}, \mathrm{s}, \mathrm{H}-2), 0.93(3 \mathrm{H}, \mathrm{s}, \mathrm{H}-13)$, 1.15 (3H, s, H-14), 2.08 (3H, s, H-15), 1.66 (1H, m, H-10b), 1.73 (1H, m, H-8b), 1.84 (1H, m, H-10a), $2.03(1 \mathrm{H}, \mathrm{m}, \mathrm{H}-8 \mathrm{a}), 3.70(1 \mathrm{H}, \mathrm{d}, J=7.4 \mathrm{~Hz}, \mathrm{H}-12 \mathrm{a}), 3.80(1 \mathrm{H}, \mathrm{d}, J=7.4 \mathrm{~Hz}, \mathrm{H}-12 \mathrm{~b}), 4.11(1 \mathrm{H}, \mathrm{m}, \mathrm{H}-9)$. ${ }^{13} \mathrm{C}-\mathrm{NMR}\left(\mathrm{CD}_{3} \mathrm{OD}, 100 \mathrm{MHz}\right) \delta$ : 168.1 (C-1), 117.8 (C-2), 150.1 (C-3), 130.4 (C-4), 133.8 (C-5), 81.8 (C-6), 86.3 (C-7), 44.6 (C-8), 64.6 (C-9), 43.1 (C-10), 75.8 (C-12), 14.9 (C-13), 18.2 (C-14), 19.8 (C-15).

Compound 7 HR-ESI-MS $m / z$ 197.1155 [M + H] ${ }^{+},{ }^{1} \mathrm{H}-\mathrm{NMR}\left(\mathrm{CD}_{3} \mathrm{OD}, 400 \mathrm{MHz}\right) \delta: 5.78(1 \mathrm{H}, \mathrm{s}, \mathrm{H}-6)$, $4.10(1 \mathrm{H}, \mathrm{m}, \mathrm{H}-2), 2.46(1 \mathrm{H}, \mathrm{m}, \mathrm{H}-3 \beta), 1.98(1 \mathrm{H}, \mathrm{m}, \mathrm{H}-1 \beta), 1.29(1 \mathrm{H}$, overlap, $\mathrm{H}-3 \alpha)$, $1.42(1 \mathrm{H}, \mathrm{t}, J=11.6 \mathrm{~Hz}, \mathrm{H}-1 \alpha), 1.59(3 \mathrm{H}, \mathrm{s}, \mathrm{H}-11), 1.31(3 \mathrm{H}, \mathrm{s}, \mathrm{H}-9), 1.28$ (3H, s, H-10). ${ }^{13} \mathrm{C}-\mathrm{NMR}$ (CD $\left.{ }_{3} \mathrm{OD}, 100 \mathrm{MHz}\right)$ 8: 49.3 (C-1), 63.8 (C-2), 47.6 (overlap, C-3), 87.1 (C-4), 182.4 (C-5), 112.3 (C-6), 172.5 (C-7), 34.7 (C-8), 23.9 (C-9), 28.9 (C-10), 24.3 (C-11).

Compound 8 ESI-MS $m / z 417.00[\mathrm{M}-\mathrm{H}]^{-},{ }^{1} \mathrm{H}-\mathrm{NMR}\left(600 \mathrm{MHz}\right.$, DMSO- $\left.d_{6}\right) \delta: 12.05(5-\mathrm{OH})$, $7.55\left(2 \mathrm{H}, \mathrm{d}, J=7.6 \mathrm{~Hz}, \mathrm{H}-2^{\prime}, 6^{\prime}\right), 7.44\left(3 \mathrm{H}, \mathrm{m}, \mathrm{H}-3^{\prime}, 4^{\prime}, 5^{\prime}\right), 6.21(1 \mathrm{H}, \mathrm{d}, J=1.5 \mathrm{~Hz}, \mathrm{H}-8)$, $6.16(1 \mathrm{H}, \mathrm{d}, J=1.5 \mathrm{~Hz}, \mathrm{H}-6), 5.66(1 \mathrm{H}, \mathrm{d}, J=12.9, \mathrm{H}-2), 4.99\left(1 \mathrm{H}, \mathrm{d}, J=7.4 \mathrm{~Hz}, \mathrm{H}-1^{\prime \prime}\right)$, $3.66(1 \mathrm{H}, \mathrm{d}, J=9.4 \mathrm{~Hz}, \mathrm{H}-6 " \mathrm{a}), 3.15-3.45$ (6H, H-3a, 2", 3", 4", 5", 6"b), 2.85 (1H, d, J = $16.7 \mathrm{~Hz}$, H-3b). ${ }^{13}$ C-NMR (150 MHz, DMSO-d $\left.d_{6}\right)$ 8: 79.1 (C-2), 42.6 (C-3), 197.3 (C-4), 163.4 (C-5), 97.1 (C-6), 165.8 (C-7), 96.0 (C-8), 163.0 (C-9), 103.7 (C-10), $138.9\left(\mathrm{C}-1^{\prime}\right), 127.2\left(\mathrm{C}-2^{\prime}\right), 129.1\left(\mathrm{C}-3^{\prime}\right), 129.1\left(\mathrm{C}-4^{\prime}\right)$, $129.1\left(\mathrm{C}-5^{\prime}\right), 127.2\left(\mathrm{C}-6^{\prime}\right), 100.0\left(\mathrm{C}-1^{\prime \prime}\right), 73.5\left(\mathrm{C}-2^{\prime \prime}\right), 76.8\left(\mathrm{C}-3^{\prime \prime}\right), 69.9\left(\mathrm{C}-4^{\prime \prime}\right), 77.6\left(\mathrm{C}-5^{\prime \prime}\right), 61.0\left(\mathrm{C}-6^{\prime \prime}\right)$.

Compound 9 ESI-MS $m / z 432.90[\mathrm{M}-\mathrm{H}]^{-},{ }^{1} \mathrm{H}-\mathrm{NMR}\left(600 \mathrm{MHz}\right.$, DMSO- $\left.d_{6}\right) \delta: 12.06(5-\mathrm{OH})$, $7.33\left(2 \mathrm{H}, \mathrm{d}, J=7.8 \mathrm{~Hz}, \mathrm{H}-2^{\prime}, 6^{\prime}\right), 6.80\left(3 \mathrm{H}, \mathrm{m}, \mathrm{H}-3^{\prime}, 5^{\prime}\right), 6.16(1 \mathrm{H}, \mathrm{d}, J=1.5 \mathrm{~Hz}, \mathrm{H}-8), 6.14(1 \mathrm{H}, \mathrm{d}, J=1.5 \mathrm{~Hz}$, H-6), $5.50(1 \mathrm{H}, \mathrm{d}, J=12.7, \mathrm{H}-2), 4.96\left(1 \mathrm{H}, \mathrm{d}, J=7.6 \mathrm{~Hz}, \mathrm{H}-1^{\prime \prime}\right), 3.67(1 \mathrm{H}, \mathrm{d}, J=9.4 \mathrm{~Hz}, \mathrm{H}-6$ "a $), 3.14-3.46$ (6H, H-3a, 2", 3", 4" , 5", 6"b), $2.74(1 \mathrm{H}, \mathrm{d}, J=16.9 \mathrm{~Hz}, \mathrm{H}-3 \mathrm{~b}) .{ }^{13} \mathrm{C}-\mathrm{NMR}(150 \mathrm{MHz}$, DMSO-d 6 ) $\delta$ : 79.1 (C-2), 42.5 (C-3), 197.7 (C-4), 163.4 (C-5), 97.0 (C-6), 165.8 (C-7), 95.9 (C-8), 163.2 (C-9), 103.7 (C-10), $129.1\left(\mathrm{C}-1^{\prime}\right), 128.9\left(\mathrm{C}-2^{\prime}\right), 115.7\left(\mathrm{C}-3^{\prime}\right), 158.3\left(\mathrm{C}-4^{\prime}\right), 115.7\left(\mathrm{C}-5^{\prime}\right), 128.9\left(\mathrm{C}-6^{\prime}\right), 100.0\left(\mathrm{C}-1^{\prime \prime}\right), 73.5\left(\mathrm{C}-2^{\prime \prime}\right)$, $76.8\left(\mathrm{C}-3^{\prime \prime}\right), 69.9\left(\mathrm{C}-4^{\prime \prime}\right), 77.5\left(\mathrm{C}-5^{\prime \prime}\right), 61.0\left(\mathrm{C}-6^{\prime \prime}\right)$.

Compound 10 ESI-MS $m / z 449.10[\mathrm{M}-\mathrm{H}]^{-},{ }^{1} \mathrm{H}-\mathrm{NMR}\left(600 \mathrm{MHz}, \mathrm{CD}_{3} \mathrm{OD}\right) \delta: 6.94\left(1 \mathrm{H}, \mathrm{brs}, \mathrm{H}^{-} 5^{\prime}\right)$, $6.80(2 \mathrm{H}$, brs, H-2', 6' $), 6.22(1 \mathrm{H}$, brs, $\mathrm{H}-8), 6.19(1 \mathrm{H}, \mathrm{brs}, \mathrm{H}-6), 5.32(1 \mathrm{H}, \mathrm{d}, J=12.6, \mathrm{H}-2)$, $4.98\left(1 \mathrm{H}, \mathrm{d}, J=7.4 \mathrm{~Hz}, \mathrm{H}-1^{\prime \prime}\right), 3.89\left(1 \mathrm{H}, \mathrm{d}, J=12.0 \mathrm{~Hz}, \mathrm{H}-6\right.$ "a), $3.70\left(1 \mathrm{H}, \mathrm{dd}, J=5.3,12.1 \mathrm{~Hz}, \mathrm{H}-6{ }^{\prime \prime} \mathrm{b}\right)$, 3.40-3.48 (4H, H-3a, 2", 3", 4"), 3.13 (1H, m, H-5"), 2.75 (1H, d, J = $17.0 \mathrm{~Hz}, \mathrm{H}-3 \mathrm{~b}) .{ }^{13} \mathrm{C}-\mathrm{NMR}(150 \mathrm{MHz}$, $\left.\mathrm{CD}_{3} \mathrm{OD}\right)$ 8: 79.3 (C-2), 42.8 (C-3), 197.1 (C-4), 163.5 (C-5), 96.6 (C-6), 165.6 (C-7), 95.5 (C-8), 163.2 (C-9), $103.5(\mathrm{C}-10), 130.1\left(\mathrm{C}-1^{\prime}\right), 113.4\left(\mathrm{C}-2^{\prime}\right), 145.1\left(\mathrm{C}-3^{\prime}\right), 145.6\left(\mathrm{C}-4^{\prime}\right), 114.9\left(\mathrm{C}-5^{\prime}\right), 118.0\left(\mathrm{C}-6^{\prime}\right), 99.8\left(\mathrm{C}-1^{\prime \prime}\right)$, $73.2\left(\mathrm{C}-2^{\prime \prime}\right), 76.4\left(\mathrm{C}-3^{\prime \prime}\right), 69.7\left(\mathrm{C}-4^{\prime \prime}\right), 76.8\left(\mathrm{C}-5^{\prime \prime}\right), 60.9\left(\mathrm{C}-6^{\prime \prime}\right)$.

Compound 11 HR-ESI-MS m/z $175.0713\left[\mathrm{M}+\mathrm{Na}{ }^{+},{ }^{1} \mathrm{H}-\mathrm{NMR}\left(\mathrm{CD}_{3} \mathrm{OD}, 400 \mathrm{MHz}\right)\right.$ 8: 7.26-7.35 $(5 \mathrm{H}, \mathrm{m}, \mathrm{H}-2,3,4,5,6), 4.34(1 \mathrm{H}, \mathrm{d}, J=7.1 \mathrm{~Hz}, \mathrm{H}-7), 3.80(1 \mathrm{H}, \mathrm{m}, \mathrm{H}-8), 0.95(3 \mathrm{H}, \mathrm{d}, J=6.4 \mathrm{~Hz}, \mathrm{H}-9)$. 


\section{Conclusions}

Two carboline alkaloids (1 and 2), five sesquiterpenoids/norsesquiterpenoids (3-7) (three of which are megastigmanes), three flavonoids (8-10), and phenylpropane-1,2-diol (11) were isolated and identified from the fruits of F. hirta for the first time. Moreover, compounds 2, 4-6, and 8-11 were reported for the first time in the Ficus genus. Pinocembrin-7-O- $\beta$-D-glucoside (8) was the major antifungal constituent against $P$. italicum existed in the fruits of Ficus hirta. Chemotaxonomic analysis revealed that the carboline alkaloid, megastigmanes, and flavonoids could be regarded as a chemotaxonomic marker of F. hirta.

Acknowledgments: This project was supported by the National Natural Science Foundation of China (31500286) and the Natural Science Foundation of Jiangxi Province (20161BAB214167).

Author Contributions: Chunpeng Wan and Jinyin Chen conceived and designed the experiments; Chunpeng Wan, Chuying Chen, Mingxi Li, Youxin Yang and Ming Chen performed the experiments; Chunpeng Wan and Chuying Chen analyzed the data; Chunpeng Wan and Jinyin Chen wrote the paper.

Conflicts of Interest: The authors declare no conflict of interest.

\section{References}

1. Flora Compilation Committee of Chinese Academy of Science. Flora of China; Science Press: Beijing, China, 1998; Volume 23, pp. 67-160.

2. Li, C.; Bu, P.B.; Qiu, D.K.; Sun, Y.F. Chemical constituents from roots of Ficus hirta. China J. Chin. Mater. Med. 2006, 31, 131-133.

3. Ya, J.; Zhang, X.Q.; Wang, Y.; Li, Y.; Ye, W. Studies on flavonoids and coumarins in the roots of Ficus hirta Vahl. Chem. Ind. For. Prod. 2008, 28, 49-52.

4. Ya, J.; Zhang, X.Q.; Wang, G.C. Flavonoids from the roots of Ficus hirta Vahl. Asia Chem. Lett. 2009, 13, 21-26.

5. Ya, J.; Zhang, X.Q.; Wang, Y.; Zhang, Q.W.; Chen, J.X.; Ye, W.C. Two new phenolic compounds from the roots of Ficus hirta. Nat. Prod. Res. 2010, 24, 621-625. [CrossRef] [PubMed]

6. Zhao, L.P.; Di, B.; Feng, F. Chemical constituents from the roots of Ficus hirta. Pharm. Clin. Res. 2008, 16, 5-7.

7. Zheng, R.R.; Ya, J.; Wang, W.J.; Yang, H.B.; Zhang, Q.W.; Zhang, X.Q.; Ye, W.C. Chemical studies on roots of Ficus hirta. China J. Chin. Mater. Med. 2013, 38, 3696-3701.

8. Jiang, B.; Liu, Z.Q.; Zeng, Y.E.; Xu, H. Chemical constituents roots of Ficus hirta. Chin. Tradit. Herb. Drugs 2005, 36, 1141-1142.

9. Yi, T.; Chen, Q.; He, X.; So, S.; Lo, Y.; Fan, L.; Chen, H. Chemical quantification and antioxidant assay of four active components in Ficus hirta root using UPLC-PAD-MS fingerprinting combined with cluster analysis. Chem. Cent. J. 2013, 7, 115. [CrossRef] [PubMed]

10. Zeng, Y.; Liu, X.; Lv, Z.; Peng, Y.H. Effects of Ficus hirta Vahl.(Wuzhimaotao) extracts on growth inhibition of HeLa cells. Exp. Toxicol. Pathol. 2012, 64, 743-749. [CrossRef] [PubMed]

11. Zhou, T.N.; Wang, Y.; Tang, L.H.; Liu, D.D.; Hou, S.Z.; Deng, X.C.; Ye, M.R. Study of Radix Fici hirtae on anti-inflammatory analgesic and effect of acute liver injury of mice. Pharm. Today 2008, 18, 55-58.

12. Zhou, T.N.; Tang, L.H.; Huang, S.C.; Lu, D.D.; Wang, Y.; Liu, L.F.; Ye, M.R. Study on the antitussive and antiasthmatic effects of radix Fici hirtae. J. Chin. Med. Mater. 2009, 32, 571-574.

13. Jia, F.L.; Ruan, M. Radix Fici hirtae protective effect of aqueous extract on acute hepatic injury in mice induced by two methyl farmamide. J. Chin. Med. Mater. 2008, 31, 1364-1368.

14. Wang, X.P.; Duan, L.J.; Huang, X.; Cen, Y.W.; Li, G.F. Protective Role Of Aqueous Extract From Fici hirtae

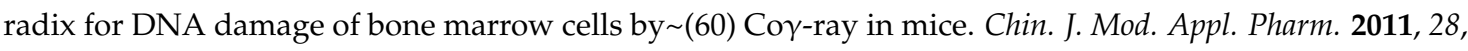
284-287.

15. Zhou, T.N.; Wang, Y.; Liu, D.D.; Tang, L.H.; Xiao, X.J.; Liu, L.F.; Ye, M.R. Experimental study on the tonic effect of different extracts from Radix Fici hirtae. J. Chin. Med. Mater. 2009, 32, 753-757.

16. Chen, Q.; Ye, S.X.; Yu, J. Antibacterial activity of Radix Fici hirtae by chromotest microassay. Med. Plant 2012, 3, 13-16.

17. Chen, C.; Wan, C.; Peng, X.; Chen, Y.; Chen, M.; Chen, J. Optimization of antifungal extracts from Ficus hirta fruits using response surface methodology and antifungal activity tests. Molecules 2015, 20, 19647-19649. [CrossRef] [PubMed] 
18. Wan, C.; Han, J.; Chen, C.; Yao, L.; Chen, J.; Yuan, T. Monosubstituted benzene derivatives from fruits of Ficus hirta and their antifungal activity against phytopathogen Penicillium italicum. J. Agric. Food Chem. 2016, 64, 5621-5624. [CrossRef] [PubMed]

19. Chen, C.; Peng, X.; Zeng, R.; Chen, M.; Wan, C.; Chen, J. Ficus hirta fruits extract incorporated into an alginate-based edible coating for Nanfeng mandarin preservation. Sci. Hortic. 2016, 202, 41-48. [CrossRef]

20. Wei, W.; Fan, C.L.; Wang, G.Y.; Tang, H.J.; Wang, Y.; Ye, W.C. Chemical constituents from Ficus pumila. Chin. Tradit. Herb. Drugs 2014, 45, 615-621.

21. Zeng, Y.; Zhang, Y.; Weng, Q.; Hu, M.; Zhong, G. Cytotoxic and insecticidal activities of derivatives of harmine, a natural insecticidal component isolated from Peganum harmala. Molecules 2010, 15, 7775-7791. [CrossRef] [PubMed]

22. Yang, N.Y.; Duan, J.A.; Li, P.; Qian, S.H. Chemical constituents of Glechoma longituba. Acta Pharm. Sin. 2006, 41, 431-434.

23. Woo, K.W.; Lee, K.R. Phytochemical constituents of Allium victorialis var. platyphyllum. Nat. Prod. Sci. 2013, 19, 221-226.

24. Cai, L.; Liu, C.S.; Fu, X.W.; Shen, X.J.; Yin, T.P.; Yang, Y.B.; Ding, Z.T. Two new glucosides from the pellicle of the walnut (Juglans regia). Nat. Prod. Bioprospect. 2012, 2, 150-153. [CrossRef]

25. He, J.B.; Niu, Y.F.; Li, J.X.; Wang, L.B.; Zi, T.P.; Yu, S.; Tao, J. Studies on terpenoids from Zygophyllum fabago. China J. Chin. Mater. Med. 2015, 40, 4634-4638.

26. Zhao, Q.; Liu, F.; Li, Q.J.; Chen, W.P. Chemical constituents from flowers of Rosa chinensis. Chin. Tradit. Herb. Drugs 2012, 43, 1484-1488.

27. Ding, Y.X.; Guo, Y.J.; Ren, Y.L.; Dou, D.; Li, Q. Isolation of flavonoids from male flowers of Eucommia ulmoides and their anti-oxidantive activities. Chin. Tradit. Herb. Drugs 2014, 45, 323-327.

28. Deng, R.X.; Zhang, C.F.; Liu, P.; Duan, W.L.; Yin, W.P. Separation and identification of flavonoids from Chinese Fringetree Flowers (Chionanthus retusa Lindl et Paxt). Food Sci. 2014, 35, 74-78.

29. Mayorga, H.; Knapp, H.; Winterhalter, P.; Duque, C. Glycosidically bound flavor compounds of cape gooseberry (Physalis peruviana L.). J. Agric. Food Chem. 2001, 49, 1904-1908.

30. Fan, M.S.; Ye, G.; Huang, C.G. The advances of chemistry and pharmacological study of Ficus genus. Nat. Prod. Res. Dev. 2005, 17, 497-504.

31. El-Hela, A.; Mohammed, A.E.; Ragab, E.; Afifi, W. Chemical constituents and biological activity of Ficus platypoda (Miq.) leaves. J. Biomed. Pharm. Res. 2014, 3, 21-37.

32. Kitajima, J.; Kimizuka, K.; Tanak, Y. Three new sesquiterpenoid glucosides of Ficus pumila fruit. Chem. Pharm. Bull. 2000, 48, 77-80. [CrossRef] [PubMed]

33. Somwong, P.; Suttisri, R.; Buakeaw, A. New sesquiterpenes and phenolic compound from Ficus foveolata. Fitoterapia 2013, 85, 1-7. [CrossRef] [PubMed]

34. Li, Y.C.; Kuo, Y.H. A monoterpenoid and two simple phenols from heartwood of Ficus microcarpa. Phytochemistry 1998, 49, 2417-2419. [CrossRef]

35. Kuo, Y.H.; Li, Y.C. Three new compounds, ficusone, ficuspirolide, and ficusolide from the heartwood of Ficus microcarpa. Chem. Pharm. Bull. 1999, 47, 299-301. [CrossRef]

36. Ammar, S.; del Mar Contreras, M.; Belguith-Hadrich, O.; Bouaziz, M.; Segura-Carretero, A. New insights into the qualitative phenolic profile of Ficus carica L. fruits and leaves from Tunisia using ultra-high-performance liquid chromatography coupled to quadrupole-time-of-flight mass spectrometry and their antioxidant activity. RSC Adv. 2015, 26, 20035-20050. [CrossRef]

37. Yang, S.; Liu, L.; Li, D.; Xia, H.; Su, X.; Peng, L.; Pan, S. Use of active extracts of poplar buds against Penicillium italicum and possible modes of action. Food Chem. 2016, 196, 610-618. [CrossRef] [PubMed]

38. Peng, L.; Yang, S.; Cheng, Y.J.; Chen, F.; Pan, S.; Fan, G. Antifungal activity and action mode of pinocembrin from propolis against Penicillium italicum. Food Sci. Biotechnol. 2012, 6, 1533-1539. [CrossRef]

(C) 2017 by the authors. Licensee MDPI, Basel, Switzerland. This article is an open access article distributed under the terms and conditions of the Creative Commons Attribution (CC BY) license (http:/ / creativecommons.org/licenses/by/4.0/). 